\title{
MISTRANSLATED NEWS REPORT ON COPENHAGEN SHOOTING IN 2015 HUMAN ERROR OR INTENTIONAL ACT?
}

\author{
Panca Javandalasta \\ pancajavandalasta@gmail.com \\ Universitas Mercu Buana
}

\author{
Cininta Aprina \\ cinintaaprina@yahoo.com \\ Yamaguchi University
}

\author{
Angkita W Kirana \\ angqtha@gmail.com \\ Universitas Airlangga
}

\begin{abstract}
The present study aims to analyze how translation in news reports can be seen unethical even though news report and translation are two aspects that should be guaranteed for its credibility, actuality, and precision. In analyzing this issue, a case of mistranslation in news reporting the Copenhagen shooting in 2015 that was published by detik.com was studied. To obtain the data, several news reports regarding the same issue that was published by several news portals around the globe in the same period of time were collected. Several reports from Indonesian news portal were also collected to see whether there was a similarity in presenting the content. The corpus-based analysis was also conducted to analyze the characters portrayed in the reports published by detik.com regarding the shooting. The result shows that only detik. com presents the mistranslated fact in the report, meanwhile the other Indonesian news sites report the contrary. The corpus-based analysis found that among the portrayed characters, Detik.com seemed to create an impression which leads the readers to think that there were two opposing sides; the suspect of shooting as the representative of the Muslim; and the cartoonist and the Ambassador which represent the non-Muslim. The mistranslated facts at detik.com seemed to please the Moslem side since, as a news site published in a country which majority citizens are Moslem, the readers of detik.com were also Muslim in the majority.
\end{abstract}

Keywords: translation, news reports, ethics, Islam

\begin{abstract}
Abstrak
Penelitian ini bertujuan untuk menganalisis bagaimana penerjemahan dalam berita tergolong tidak etis meskipun berita dan terjemahan adalah dua aspek yang harus dijamin kredibilitas, aktualitas dan ketepatannya. Dalam menganalisa masalah ini, kasus penerjemahan dalam berita yang melaporkan Penembakan Coppenhagen pada tahun 2015 yang diterbitkan oleh detik.com diangkat sebagai studi kasus. Data diperoleh dari kumpulan beberapa berita tentang masalah yang sama yang dipublikasikan oleh beberapa portal berita di seluruh dunia dalam periode waktu yang sama. Beberapa laporan dari portal berita Indonesia juga dikumpulkan untuk melihat apakah ada kesamaan dalam menyajikan konten. Analisis berbasis Corpus juga dilakukan untuk menganalisis karakter-karakter yang digambarkan dalam laporan yang diterbitkan oleh detik.com mengenai penembakan. Hasilnya menunjukkan bahwa hanya detik.com menyajikan fakta yang salah diterjemahkan dalam laporan tersebut, sementara situs berita Indonesia lainnya melaporkan sebaliknya. Analisis berbasis korpus menemukan bahwa di antara karakter yang digambarkan, Detik.com tampaknya menciptakan kesan yang membuat para pembaca berpikir bahwa ada dua sisi yang berlawanan; tersangka penembakan sebagai wakil Muslim; dan kartunis dan Duta Besar yang mewakili non-muslim. Fakta-fakta yang salah diterjemahkan di detik.com tampaknya menyenangkan pihak Muslim sejak, sebagai situs berita yang diterbitkan di negara yang mayoritas warga negara Muslim, pembaca detik.com juga mayoritas Muslim.
\end{abstract}

Kata Kunci: penerjemahan, berita, kode etik, Islam 


\section{INTRODUCTION}

One of the functions of media in society is to give a glimpse of information to the people. This function is utilized at the optimum level with the help of technology, as in this context is the internet. The advancement of the internet has changed the way of how information such as news is spread. Currently, journalism has already shifted its conventional paper-based distribution method into online (Romli, 2012). Online journalism is known to be journalism activity that utilizes the internet as the medium to broadcast news in order to be able to be accessed globally (Romli, 2012).

However, since there are so many languages spoken in the world and a certain event that attracts global attention might occur in one part of the world, translation is required. The source of the news might be delivered in particular language which is not spoken in another part of the world. Therefore, the service of translation is needed to facilitate the news consumers in another part of the world to understand things that are going on. Yet, regarding the meaning of particular terms in one language might be different in another language, the difference of interpretation in gaining the meaning might happen. This might cause misinterpretation or purposive change of interpretation through a process of translating.

The translated news might contain particular framing since news reporting always involves commentary, stance and ideological manipulation (Fairclough, 1995). Hacket (1984) argued, news media concepts the bias, or its commonly accepted opposite, objectivity, as its role in politic and ideology. Thus, the information shared in the news, though report the factual events, might be inserted particular framing towards particular character portrayed in the news reported. Several news websites in Indonesia offer international sites which inform things happened in the other nations. To get the information, it is more likely for the Indonesian journalists or the editor to adapt or retell the information published by the media for that particular country. The information then is translated so that Indonesian readers can understand the information since not every citizen of Indonesia can speak a foreign language.

The bias nature of the news and the equal nature of translation thus might give a challenge for the translator of the news. As Floros (2012) argued, there is an issue in regards to significantly transforming the news items as they cross boundaries and (audience) expectations. In addition, there is also discussion on the ideological implications of the transforming practices applied in order to tailor a news item for a different audience. In other words, there are several factors that need consideration in applying translation process. On one hand, it is necessary to keep the meaning and the sense of the information taken from the source text (the news that is adapted) into the target text (the news delivered in the target language). However, on the other 
hand, it might also important to either keep the news to be neutral or be adjusted with the ideology of the parties involved in the publishing of the news in that area. This difference ideology might be caused by the difference in the cultural background in each nation. This cause the difference in delivering the information.

One example of the difference in delivering the information can be seen on the recent news about the death of famous singer, George Michael. Due to the death of the famous artist, there are several news websites wrote about it. Also, since George Michael was pretty famous in Indonesia, the information was also announced in Indonesian news websites. However, since Britain, the country where Michael dead, has a different culture in gender issue with Indonesia, there must be the difference in the way the news is written. This is proven in the website of BBC UK and BBC Indonesia. There are a lot of things that BBC UK wrote about the death of the artists including the affairs, troubles, and his homosexuality (George Michael: Pop superstar dies at 53, 2016). However, that information is not mentioned in BBC Indonesia. Even though both websites use the equal headline, "Bintang pop George Michael meninggal dunia pada usia 53 tahun" for BBC Indonesia, the information contained is not as much as BBC UK. The issue about the singer's affair and sexuality is not mentioned (Bintang pop George Michael meninggal dunia pada usia 53 tahun, 2016). The news, in Indonesian version, gives different impact towards Indonesian citizen than when the news is read in UK version by Indonesian citizen as in Indonesia, issues about gay are still considered taboo. If such topic can be delivered in a different way to be adjusted with readers', it is possible that more serious topics will be manipulated in such a way in the writing either to build readers' point of view or to be adjusted to readers' culture.

To some point, manipulating the content of certain news by writing a translation of it in such a way might not cause harmful things as manipulation sometimes is necessary if there are no equivalent words in the target language (Baker, 2011). The manipulation can be carried out to satisfy the target medium in various ways (Bani, 2006) such as by adjusting it to the needs of the reader, reorganizing the text, cutting, changing the structure of the paragraphs, altering the syntax in accordance of editorial stylistic norms or inserting necessary explanations (Claramonte, 1996, in Bani, 2006). This is carried out to guide readers' comprehension and interpretation towards the news content.

Even though manipulation in translating the news is common due to the necessity, the translation is considered unethical if it creates misinterpretation due to the wrong undertanding of the source text which causes prejudiced, biased, ideologically suspect version, and as a result, such a condition will have unethical consequences for the relations and perceptions of the source and target cultures (Chesterman, 2001). In 
the process of translating, sometimes, there are terms in one language that has no equivalent, therefore the strategy in finding the most similar term in the target language can be chosen. However, since the chosen term is only similar, there might be some meaning that is not conveyed. But, if the chosen words in the target language do not state things that exist in the source text, it is also considered as unethical (Pym, 2001). Such unethical translation should be avoided as it can cause issues that might affect the relationship of nations.

Problems arose due to unethical translation have occurred in many countries (Orengo, 2005; Kang, 2007). One of them even heighten the tension of cold war between Russia and America as the Russian Premier's statement, "we will bury you" that was uttered in Russian language, was simply translated into English without considering the cultural meaning of the idioms in Russian culture and merely seen in American culture (Birkby, 2015). The utterance then considered as the threat towards western countries during the cold war in the 1950s. Floros (2012) study the use of translation in news production in the context of the conflicted area, Cypriot. The data were taken from examples from newspapers and English-language press reviews of the Press and Information Office of the Republic of Cyprus. Cypriot once becomes a democratic state which populated with Greek Cypriot as the majority and Turkish Cypriot as the minority. Due to some circumstances, the nation was considered divided into two area as both Turkey and Greek claim to occupy the nation. The two conflicting countries use two different languages and name the institution in their own terms. The data point to the assumption that translation is used for disseminating and consolidating national policy in ways which might stand in a conflicting relationship with issues pertaining to translation ethics.

Learning from the issues occurred in Cypriot, the same issue is possible to happen in Indonesia since there are a lot of ethnic communities live in the country. Each of them might have their own religion, speak their own language and hold on their own ideologies. It is nearly impossible to present the news adjusting the preference of each community. Therefore, the ways in which the news produced and served might be adjusted to particular communities. The probability of manipulation in constructing the news content through violation in translation ethics might also occur. Thus, this study presents the case of violation in translation ethics and discuss the reason behind the occurrence.

To discuss this issue, a case of shooting in Copenhagen in 2015 that involved satiric cartoonist Lars Vilk is chosen. This discussion is noted to be interesting since the issue of religion is considered to be one of the sensitive issues in this country which majority citizen is Muslim. The data are taken from several online news websites from 
Europe, America, Middle East, and Indonesia. Europe and America are chosen as the majority of the population is not Muslim community. Moreover, the incident occurred in the European country. Meanwhile, the news website from the Middle East is chosen as a comparison to give insight based on Muslim point of view since the majority of communities in the Middle East are Muslim. The Indonesian website studied is DetikNews since the example of a violation of ethical codes in translation is found in it. Several other websites publish in Indonesia is also chosen as a consideration of the validity of the data presented in DetikNews. In short, the present study is trying to find what can be the reasons of mistranslating news on DetikNews website in the case of Copenhagen shooting.

\section{THEORETICAL REVIEW}

Flanagin and Metzger (2000) explained that, unlike Internet-based news site, conventional media underwent verification process as well as conducting multiple rechecking before presenting the news to the public. This might be taken as one of the characteristics of online journalism was Immediacy and that it is important for news to be fast and freshly to be reported to the public (Ward, 2002). Therefore, this demand might violate the properness of the news presentation itself. Kusumaningrat and Kusumaningrat (2009) stated that the news is considered proper if it is:

1. accurate

The accuracy of a news does not only cover the precision in presenting the name spelling, numbers, dates, and age, but also the precision in presenting the impression regarding the events reported in order give the right impression. The right impression in reporting point of view can be achieved by providing the details of facts as well as the tension that those details expressed.

2. Complete, fair and balance

These can be achieved by presenting the events the way it happened

3. Objective

The objectivity is achieved by presenting the whole events based on the facts without the inclusion of subjective tendency.

4. Brief

A news report should be brief in order to be effective

5. Fresh

News should be presented as immediately as possible.

\section{The Process of News Reporting}

There are three stages conducted by News Departement Detikcom in reporting the news (kusumaningrat \& kusumaningrat, 2009). Those stages are: 
a. Pre-Reporting

At this stage, the journalists make preparation regarding the news that is to be reported. This stage involved the understanding and coordinating of the report material that is given by the coordinator, preparing the interview instruments and other technical support.

b. Reporting

At this stage, the reporter is expected to be able to look for concrete and complete data at the field by answering the $5 \mathrm{~W}+1 \mathrm{H}$ (What, Who, Where, When, Why+How) questions.

c. Post-Reporting

The third stage is the process of writing the news report before it is presented to the readers. In the process of writing, the reporter makes the article draft that is to be examined by the news producer. The producer checks the data presented and see if any correction is needed. After being examined, the draft is sent to the reporter to be revised and edited by giving necessary pictures to synchronize the plot portrayed in the news. The final draft is then published as the article.

\section{How translation is processed}

In relation with news translation, Bani (2006), who analyze this process from an Italian news media, there are steps that are needed to be taken in translating news from one source language into target language. These steps involve many other participants than the translators themselves. Since the news presented in a particular media might contain an ideological and political point of view of the editorial board, the similar topic and source are favored. Therefore, the first step of the process is analyzing the selected sources which discuss issues which are to be presented. This step is taken by the editors of the news media. Any information about the issue is analyzed from similar articles published in the most important and prestigious newspapers from all over the world. They also monitor some discussions of that particular issue in minor newspapers. These are done in order to find if there is another different point of view on that specific issue.

The second step taken is choosing the of text to be translated. Bani (2006) argued that there are various reasons that drive to the choice such as the reputation of the author or source with considering the figures portrayed in the topic. This means, the character reported in the news also plays important role in attracting the readers. The other reasons are the stylistic issues, subject matter, and the way the public see that particular media. It is considered important to mind the subject matter as an important topic in Italy might not become the concern of people in Malaysia or other countries. 
Therefore the choice of topic is also adjusted with the preference of the reader. In addition, it is also considered important to maintain the public impression of the media. Thus, the presentation of the news also becomes the concern of the editors.

After the original text is selected, it is sent to the translator to create the actual translation. In her study, Bani (2006) argued that the translators working in the news media she discussed have a couple of characteristics that influence the translation strategies. The first characteristic requires the translator to be invisible as they are not given much space compared to the author. In addition, the translation itself is only a device to render the target text into many of those written in target language so that the reader will only make the least effort in understanding the text. The second characteristic is loyalty. This is related to the section in which the translated text will be published. Each section has a particular degree of informativity, therefore translators know how far they can push their degree of reformulation. Nord (2014) also argued that compare to the other participants involved in the news media, often translators are the only real experts from the linguistic and cultural point of view who are able to appreciate the original text fully. Therefore, when proofreading, editors tend to trust the translators' choices.

The process of news translation does not end right after the translation is completed. The translated text goes back to the editorial office and is considered a draft which is then revised by several figures (Bani, 2006). During the time, the draft gets through several other steps. Firstly, an editor checks the target text against the source text (target translation - source text); secondly, another editor proofreads the translated version. Then, a copy editor takes care of where the translation will be inserted into the newspaper. And finally, the director checks it. From the steps taken from the raw materials into an article ready to be published, the text is checked several times both the content and the presentation. From the several layers of checking and proofreading, mistranslation would be very unlikely to appear in the published article.

\section{How Mistranslation Occurs}

According to Vinay and Darbelnet (1995), there are two methods that can be applied in translation. The first is Direct Translation Method which transposes the source language message element by element into the target language. However since there might be several gaps in the concept of the target language and the source language, borrowing, calque and literal translation sometimes necessary to be taken. The second method is Oblique Translation Method. This method is taken when there are structural or metalinguistic differences that make certain stylistic effects cannot be transposed into the TL without upsetting the syntactic order, or even the lexis. Therefore, transposition, modulation, equivalence, and adaptation are taken into 
consideration in translating the text. nevertheless, regarding the methods taken, there is an assumption that translators first serve the culture into which they are translating in order to reinforce the norms which concern about things such as what translators think they are supposed to do, what clients think translators ought to do, what textusers think a translation should be like, and what kind of translations are considered reprehensible or laudable within the system. This makes the result of translation is expected to meet the norms in the target language. In order to do so, several procedures of translating are taken especially when there is a gap in the language.

Pormouzeh (2014) believed that even though translators and interpreters are expected to take the neutral position, but practically it is not possible, because they are rented by commissioners and institutions in order to obey the respected values of those organizations as in some conflicting situation are driven by the different narrations of the same fact. Depending on the aim of the translation, the translator may need to make some changes in the source text such as omitting some part of the text, expanding the information by providing fotnotes or glossary, updating the outdated, old-fashioned and obscure information in the source text with modern equivalents, exoticism or the substitution of some culture specific words like slangs, dialects etc. in the source text by equivalents in the target text, and inserting a more familiar and suitable context in the target readers' culture if the translator believes that the one used in the source text is less common and suitable (Sertkan, 2007).

However, in achieving this expected translation result, there are possibilities that the translation might violate the ethics as translation is also influenced by various aims owned by the parties or organizations that hired the translators. A translation is considered to violate the ethics for several reasons. First, the translator shouldn't forget that their translations are the representatives of the source text, or the writer (Pym, 2001). If something exists in the source text but it doesn't exist in the translated version, it is not ethical and also the translator is responsible and guilty for it. Chesterman (2001) also argued that, if a translation "misinterprets" a source text, the result will be a prejudiced, biased, ideologically suspect version, and as a result, such a condition will have unethical consequences for the relations and perceptions of the source and target cultures. These kind of translations are those that violate the ethics. He also added that a good translator is like a good mirror which should reflect the source text, or the source text's writers aim and the source culture in a faithful way. He also sees the "ethical translator" as a mediator, whose responsibility is to work to achieve crosscultural understanding. 


\section{RESEARCH METHOD}

As illustrated in the previous section, the focus of the study is to analyze the possible reasons of the mistranslating in DetikNews report about shootings in Copenhagen on February 2015. However, before the data presentation, it is considered necessary to explain the chronology of the event. The shootings in Copenhagen was believed to be one of a sequential act of protest towards the cartoonist for portraying Prophet Muhammad in a caricature that offensively illustrates the Prophet. The shootings occurred in two consecutive days in two different places. However, the study discussed the shootings in the second days which occurred during a meeting of the cartoonist and French Ambassador. In addition, the data in questions is in regards to the condition of Lars Vilks, the satirical cartoonist, and French ambassador for Denmark, Francois Zimeray.

In analyzing the issue, the portrayal of characters involved in the news was also explained. This was taken to find whether there was an opposing side between the characters involved in the news. Shojaei and Laheghi (2012) argue that, in news translation, political ideology and control factors were some of the factors in translating a text which influences the result of the translation process. This imposes some limitations and gives direction to the translator. Therefore, finding the characters that were portrayed in the news might give insights about the ideologies that might become a consideration in producing the translation results the way they are presented in news. In analyzing this, a corpus-based analysis was applied. This part of the discussion was analyzed by collecting every article published by Detiknews about shootings in Copenhagen on February 2015. Those articles were then saved in plain text format and analyzed using Antconc application. The writers focused on the characters who were most frequently mentioned (the data was obtained by simply checking the wordlist menu in the application). The portrayal of the characters was obtained by analyzing their collocation which could be seen in concordance list menu.

The second point to analyze was the mistranslation itself. This study explained the occurrence of the mistranslation, how it might violate the translation ethics, as well as the possibility of intentional mistranslation. The first step taken was to find the validity of the information. In order to do so, similar reports that were published in the same period from several online news in several countries were also collected. Those news sites were BBC UK, The Guardian, VOA Indonesia, Sindonews, BBC Indonesia, Reuters, and Al Jazeera. Those news sites were chosen with the consideration of that they represent the value and believe they holds towards Moslem particularly and the event in general sense; The European news site represent European readers' point of views as the occurence occured in European country, Al Jazeera represent the Middle 
Eastern which expected to give insight of the point of views of the readers in Moslem countries, The American news site was expected to show the it from the Non-Moslem perspectives, and the Indonesian news sites represent the point of views from the readers from a country which mosly populated by Moslem. The second step taken was finding whether the other Indonesian news sites also gave similar translation regarding the issue. Another reason why checking whether there was a similar way in translating the news was that those news sites were intended to be read by Indonesian readers. Even though each of Indonesian news site that was taken into consideration in this study might have its own target readers, the distribution of it was still in Indonesia, therefore it could be assumed that the target readers might share a similar point of view regarding the news.

The findings of this study were analyzed both in the point of view of translation ethics theories and media. The process in publishing the news also gave contribution in the news that was presented to the public.

\section{RESULT AND DISCUSSION}

\section{Result Presentation}

There are seven articles about the issue found in DetikNews reports. Those articles were published from 15 - 18 February 2015. Among those articles, there were six characters which were the most frequently mentioned; The suspect (30 times); the victims (22 times); Lars Vilk (10 times); Islam (five times); French Ambassador for Denmark, Francois Zimeray (5 times); and America (three times). The concordance list of the suspect showed the portrayal of the suspect as a Muslim young man with criminal records and had contact with ISIS. The suspect was also described as a young man who got offended when his Prophet was portrayed in offensive ways by the cartoonist he tried to shoot. Another character, the victim, was focused in several ways; the dead ones (12 times); the injured ones (six times); and those were unharmed (four times).

The fact that dead victims were mentioned two times more frequent than the injured ones might be done in order to describe the brutality of the suspect and the terror that the attack had caused. This could lead the readers' impression and label the suspect to be blinded by his anger towards the cartoonist, ignoring the safety of innocent people. Even though the suspect was described as the ruthless character, Lars Vilk, the cartoonist, was described as the one who triggers the anger of the suspect by picturing the Prophet of Muslim in offensive ways in the first place. Therefore, the act of shooting was seen as punishment towards the guilty one, the cartoonist (at least in Muslim's point of view since Prophet of Muslim should be seen, described, mentioned 
and portrayed in positive ways).

Among the articles, the French Ambassador, Francois Zimeray described as a politically important person who attended the discussion event upon which the attack targeted, thus he was portrayed as a person who supported the cartoonist. This fact leads to an impression of the ambassador to be as guilty as the cartoonist, at least in the point of view of those who thought that the act of portraying the Prophet to be improper, just like the suspect in this case. Other than the ambassador, Islam as a religion also mentioned along with the words and phrases "militant", "armed", Prophets are not to be pictured" and "freedom to contend". This portrayed Islam as a stiff and militant religion. The last character was America. From the few mentions, it is portrayed among those who censure the attack.

There are two conflicting reports about the condition of both Lars Vilks and Francois Zimeray among the news analyzed. DetikNews which report is taken from European news source, present contrary data compare to the other news website. The article in DetikNews is illustrated as follows:

1. Polisi Cari Pelaku Penembakan Cafe Krudttoenden di Denmark yang Kabur Polisi Denmark mengkonfirmasi bahwa seorang warga sipil tewas dan mengatakan, kedua tersangka telah melarikan diri di dalam mobil setelah serangan terhadap pertemuan tersebut, yang merupakan perdebatan tentang seni dan penghujatan.

Vilks dan duta besar Perancis, yang juga hadir, keduanya terluka. [...]

Danish police confirmed that a civilian was killed and said the two suspects had fled in a car after the attack on the meeting, which is a debate about art and blasphemy.

Vilks and the French ambassador, who was also present, both injured. [...]

(Polisi Cari Pelaku Penembakan Cafe Krudttoenden di Denmark yang Kabur, 2015)

The extract from the article shows that the cartoonist, Vilks, and French Ambassador to Denmark, Francois Zimeray, were present at the event, and thus harmed during the attack. In the article, all of the photographs were taken from Reuters. However, in the article published by Reuters in the same day, there is no report about the condition of the two persons that is stated explicitly (Zawadzki \& Mickelsen, 2015). There is only report that a film-maker and a guard had died during the attack.

2. Danish police kill 22-year-old suspected of Copenhagen shootings

Two civilians - a synagogue guard and a film-maker - were killed and five police were wounded in the two separate attacks in the Danish capital on Saturday and Sunday. [...]

(Zawadzki \& Mickelsen, 2015) 
The other report about the attack was taken from BBC. The website also reported that both Lars Viljk and Embassador Zimeray were unhurt.

3. Copenhagen shooting: One dead in deadly seminar attack

Several dozen shots were fired at the seminar and a manhunt is now under way.

Prime Minister Helle Thorning-Schmidt described it as a "politically motivated" act of terrorism.

Cartoonist Lars Vilks, who has faced death threats over his caricatures of the Prophet Muhammad, was unhurt. [...]

The French ambassador, Francois Zimeray, was also present during the attack.

Shortly after the shooting, a message appeared on his Twitter feed saying he was still alive. [...]

(Copenhagen shooting: One dead in deadly seminar attack, 2015)

Moreover, American news website, The Guardian, also wrote that both persons were safe

4. One dead and three injured in Copenhagen 'terrorist attack'

[...] Neither Vilks nor Zimeray were injured, but at least one person was killed in the attack at about 3 pm GMT. The gunmen fled the scene by car. [...]

(One dead and three injured in Copenhagen 'terrorist attack', 2015)

In addition, Al Jazeera also reported that both persons were unharmed

5. Denmark on high alert after the attack on the free-speech event

[...]Francois Zimeray, the French ambassador to Denmark, was in attendance when the event at the Krudttoenden Cafe came under attack.

He was not injured. [...]

Artist not injured.[...]

(Denmark on high alert after attack on free-speech event, 2015)

The reports from Reuters, BBC, The Guardian, and Al Jazeera stated that both Lars Vilk and Ambassador Zimeray were safe and unharmed. However, on the contrary, the news reported by DetikNews stated that both were harmed (terluka, as it is stated in the report).

DetikNews also provided the contrary compared to other Indonesian news agencies. This was expressed in the report issued by VOA Indonesia.

6. Polisi Denmark Tembak Tewas Tersangka Pelaku Penembakan di Kopenhagen [...]Dalam serangan pertama, seorang laki-laki dengan senjata otomatis menembak satu orang dan melukai tiga polisi di sebuah café. Media Denmark 
mengenali korban tewas itu sebagai sutradara film Finn Norgaard yang berusia 55 tahun. Acara mimbar bebas itu juga dihadiri kartunis Swedia Lars Vilks yang dikenal dengan karikatur-karikaturnya yang provokatif, termasuk karikatur Nabi Muhammad SAW tahun 2007 yang memicu ancaman terhadap kartunis berusia 68 tahun itu. Duta Besar Perancis Untuk Denmark Francois Zimeray juga menghadiri acara itu. Keduanya selamat. [...]

[...] In the first attack, a man with an automatic weapon to shoot one person and wounded three policemen in a café. Danish media to recognize the dead as a film director Finn Norgaard 55 years. Free speech event was also attended by Swedish cartoonist Lars Vilks who is known for his caricatures caricature-provocative, including caricatures of the Prophet Muhammad in 2007 that triggered the threat to 68-year-old cartoonist. French ambassador Francois Zimeray for Denmark also attended the event. Both were survived.[...]

(Polisi Denmark Tembak Tewas Tersangka Pelaku Penembakan di Kopenhagen, 2015)

Another news website which stated similar report was Sindonews. Spreading the news from $\mathrm{ABC}$, Sindonews reported:

7. Lars Vilks, Target Utama Penembakan Copenhagen

[...] Kartunis Swedia itu sendiri lolos dari serangan tersebut tanpa luka sedikipun. Dirinya selamat, karena berhasil melarikan diri lewat pintu belakang gedung.[...]

The Swedish cartoonist himself escaped the attack without injuries. He was safe because he managed to escape through the back door of the building [...] (Maulana, 2015)

Even though there is no report about the ambassador in the report of Sindonews, it is clearly stated that the cartoonist was safe with no wound at all. The reports from the two Indonesian news website contradicted the report issued by DetikNews about the condition of the cartoonist and the ambassador.

\section{Discussion}

In this case, among the portrayal of the characters, Detiknews seemed to create an impression which led the readers to think that there were two opposing sides. In other words, the bias. On one side, it is the side of the suspect as the representative of the Muslim. The other side belongs to the cartoonist which represent the non-muslim. Detiknews is a news media which base is in Indonesia, a country which majority of the citizen is Muslim. Thus, the implication of it could be that the majority of the Detiknews readers is Muslim. Therefore, implicitly showing the tendency towards the Muslim side could be expected from this news media since it is important for the news 
media to obtain good impression from its readers. In other words, the presentation of the news could be adjusted in such a way to satisfy the readers' preference.

The contrary report might happen due to some reasons. The first reason that probably causes this to happen is the inability of the translator in understanding the vocabulary used in the source news. Some news website and press agency clearly stated that the persons in question were unharmed. To note this, the fourth news website uses different approach and vocabulary. Reuters stated "Two civilians - a synagogue guard and a film-maker - were killed and five police were wounded" which clearly implies that the artist/cartoonist and the ambassador were safe and unharmed since the dead were a guard and a filmmaker, and the wounded were police. Meanwhile, BBC, use different approach and vocabulary to note the condition of those people. It chose the word unhurt to describe the artist's condition and "still alive" for the ambassador. The Guardian, on the other hand, chose negation conjunction "neither ... nor" preceding the adjective "injured" to describe their condition. At last, Al Jazeera used negation marker "not" followed by adjective "injured" to describe it. Every attempt and vocabularies chosen was clearly implied the same thing.

Baker (2011) implied that translation requires natural ability and skill, practice and general knowledge of the translator. In other words, to produce a good translation, the translator needs to have sufficient amount of comprehension in both source and target language. Thus, the translator should be aware of the meaning conveyed in the vocabularies used in source language able to convert them into its equivalent in the target language. The translator, or journalist in this context, had managed to convert most of the report in the source language, English, into the target language, Bahasa Indonesia. It would be odd if they were missed in converting this one clear and frequently appeared vocabulary into its properly equivalent term in the target language. Moreover, translation also requires a significant degree of resemblance or correspondence with respect to the source text (Colina, 2015). In other words, in order to produce a valid, the translator should be aware that they may not change the meaning intended in the source language.

The online news report is demanded to be actual and up to date to maintain the freshness of the news (Ward, 2002). This unfortunately compromised the credibility in the news content. This occurred as online journalism underwent less verification processed compared to conventional journalism (Flanagin \& Metzger, 2000). Therefore, since the report in this study was expected to undergo examination from the news producers, it seems not enough to meet the accuracy standard since the mistranslation remained unrevised. Thus, there was a possibility in questioning the credibility of the news reported. 
Considering that the mistranslation occurred due to human error could be quite frivolous since English widely known in Indonesia. It is known that news agencies compete with each other to provide the most factual news. Contradiction in the report might cause problems for the agencies since it can lead them to be distrusted by their reader as their reports are considered to be not factual. Thus, it is highly possible that each news agencies will avoid such errors. In other words, the reports issued by every agency about the incident could be expected to be in accordance with each other.

Apart from the personal quality of the translator, ideology of the translator and the other parties involved in the news production can also give influence to the product of translation which in this context, is the news itself. Baumgarten (2010) defined ideology to be rooted in individual and social consciousness. Therefore, it regulates how people perceive the world, what they know and believe about it. He also argued that it is closely related to perception, knowledge, and beliefs. Thus it determines what people regard as the aesthetic or factual truth at a certain place and time. The ideology of every person is different as it is also affected by the culture in the place they live. Therefore, it is possible that the difference in meaning that occurred in the translation in the news was intentional in order to be adjusted to the ideology of either the translator, the other parties involved, the target readers, or even all of them. Baumgarten also argues that sometimes in order to adjust with the target language which could be spoken by people of a different culture (thus, might possess different ideology), changing in the quantity of meaning conveyed from the source language might be the strategies taken by the translators.

However, the news is expected to be objective, free from value judgment, and balance (Flanagin, \& Metzger, 2000; Nozato, 2002; Kusumaningrat \& Kusumaningrat, 2009). The mistranslated fact in this report could create stress toward the particular side and lead to the emergence of particular interpretation towards the characters portrayed in the news. The leaning interpretation could corner particular character by indicating negative evaluation. Presenting displeasing situation of a particular character, in this context the harmed Ambassador and Viljk as the ones violating Islamic culture for portraying Moslem's Prophet, might give satisfaction to the readers of detik.com that are mostly Moslem. In this case, the mistranslation might be intentionally done in order to show the side in which the news agency stands.

This strategy might be chosen as the majority of the Indonesian population is Muslim. It is possible that the ideology of most readers of detik.com is based on Muslim ideology. Prophet Muhammad is considered to be an awliya or a saint in Muslim belief. Thus the portrayal of him should always be in noble ways. However, the incident discussed occurred after the cartoonist, Lars Vilk, involved in the publishing 
of offensive portrayal of Prophet Muhammad which rose global protests on the side of Muslim towards the cartoonists, including Lars Vilks. The shootings targetted the cartoonist. Therefore, it was possible that if the report in the news presented that the attack, in some ways, managed to give the cartoonist, who was accused to be guilty, punishment, it would be in accordance with the ideology that is adhered in Indonesia. This accordance might be expected to raise the favor of readers towards the agency since the report presented satisfies the readers' preference.

\section{CONCLUSION}

Translation and news production can be used as a tool both to spread information and build particular portrayal of characters described in the text which in this context, the news. Changing some parts of the meaning conveyed in the source language in an attempt to give equivalent meaning in the target language in the practice of translation become one of the strategies chosen by the translator. However, changing the entire meaning which creates contrary understanding towards the source text, as what the DetikNews had done in the news about shooting in Copenhagen, is unethical. It is considered to be unethical since, regardless the reasons behind the practice, intentionally create misinterpretation which can cause prejudiced, biased, ideologically suspect version, might cause consequences for the relations and perceptions of the source and target cultures as well as the global population.

\section{REFERENCES}

Baker, M. (2011). In Other Words: A Course Book on Translation (2nd ed.). New York: Routledge.

Bani, S. (2006). An analysis of press translation process. Translation in Global News (pp. 35-45). Coventry: The Centre for Translation and Comparative Cultural Studies.

Baumgarten, S. (2010). Ideologies and Translation. In Y. Gambier, \& L. van Doorslaer (Eds.), Handbook of Translation Studies (Vol. III, pp. 59-65). Amsterdam: John Benjamins Publishing Co.

Bintang pop George Michael meninggal dunia pada usia 53 tahun. (2016, December

26). Retrieved from BBC: http://www.bbc.com/indonesia/majalah-38432498

Birkby, S. J. (2015). We will bury you'how mistranslation heightened cold war tensions. Chesterman, A. (2001). Proposal for a Hieronymic oath. The translator, 7(2), 139-154. Colina, Sonia. 2015. Fundamentals of Translation. Cambridge: Cambridge University 
Press.

Copenhagen shooting: One dead in deadly seminar attack. (2015, 2 14). Retrieved from BBC: http://www.bbc.com/news/world-europe-31472423

Denmark on high alert after attack on free-speech event. (2015, February 15). Retrieved from Al Jazeera: http://www.aljazeera.com/news/2015/02/shots-fired-denmarkcafe-free-speech-event-150214160339729.html

Fairclough, Norman (1995): Media Discourse. London: Arnold.

Flanagin, A. J., \& Metzger, M. J. (2000). Perceptions of Internet information credibility. Journalism \& Mass Communication Quarterly, 77(3), 515-540.

Floros, G. (2012). News translation and translation ethics in the Cypriot context. Meta: Translators' Journal, 57(4), 924-942.

George Michael: Pop superstar dies at 53. (2016, December 26). Retrieved from BBC: http://www.bbc.com/news/uk-38432862

Hackett, R. a. (1984). Decline of a paradigm? Bias and objectivity in news media studies. Critical Studies in Mass Communication, 1(3), 229-259.

Kang, J. H. (2007). Recontextualization of news discourse: A case study of translation of news discourse on North Korea. Translator, 13(2), 219-242.

Kusumaningrat, H., \& Kusumaningrat, P. (2009). Jurnalistik Teori \& Praktik. Bandung: Remaja Rosdakarya.

Maulana, V. (2015, February 15). Lars Vilks, Target Utama Penembakan

Copenhagen. Retrieved from Sindonews: http://international.sindonews.com/ read/964648/41/lars-vilks-target-utama-penembakan-copenhagen-1423983676

Nord, C. (2014). Translating as a purposeful activity: Functionalist approaches explained. Routledge.

One dead and three injured in Copenhagen 'terrorist attack'. (2015, February 14). Retrieved from The Guardian: https://www.theguardian.com/world/2015/feb/14/ copenhagen-blasphemy-lars-vilks-prophet-muhammad-krudttonden-cafe

Nozato, Y. (2002). Credibility of online newspapers. Recuperado el, 29.

Orengo, A. (2005). Localising News: Translation and the "Global-national" Dichotomy. Language and Intercultural Communication, 5(2), 168-187.

Polisi Cari Pelaku Penembakan Cafe Krudttoenden di Denmark yang Kabur. (2015, February 15). Retrieved from Detiknews: http://news.detik.com/ internasional/d-2833375/polisi-cari-pelaku-penembakan-cafe-krudttoenden-didenmark-yang-kabur

Polisi Denmark Tembak Tewas Tersangka Pelaku Penembakan di Kopenhagen. (2015, February 15). Retrieved from VOA Indonesia: http://www.voaindonesia. $\mathrm{com} / \mathrm{a} /$ polisi-percaya-telah-tembak-mati-tersangka-pelaku-penembakan-di- 
copenhagen/2644930.html

Pormouzeh, A. (2014). Translation as Renarration: Critical Analysis of Iran's Cultural and Political News in English Western Media and Press from 2000 to 2012. Mediterranean Journal of Social Sciences, 5(9), 608.

Pym, A. (2001). Introduction: The return to ethics in translation studies. The Translator, 7(2), 129-138.

Pym, Anthony. 2014. Exploring translation theories (2nd ed.). Routledge.

Romli, A.S.M. (2012). Jurnalistik Online. Bandung: Nuansa.

Sertkan, K. (2007). The Ideology of Lexical Choices in the Turkish Translations of “Oliver Twist”. Diss. Dokuz Eylül U, 2007.

Shojaei, A., \& Laheghi, F. (2012). A critical discourse analysis of political ideology and control factors in news translation. Theory and practice in language studies, 2(12), 2535.

Vinay, Jean-Paul \& Darbelnet, Jean. 1995. Comparative Stylistics of French and English: A methodology for translation. Amsterdam: John Benjamins.

Ward, M. (2002). Journalism Online. Oxford: Focal Press.

Zawadzki, S., \& Mickelsen, O. (2015, February 15). Danish police kill 22-year-old suspected of Copenhagen Shootings. Retrieved from Reuters: http://www. reuters.com/article/us-denmark-shootings-idUSKBN0LI0N720150215 